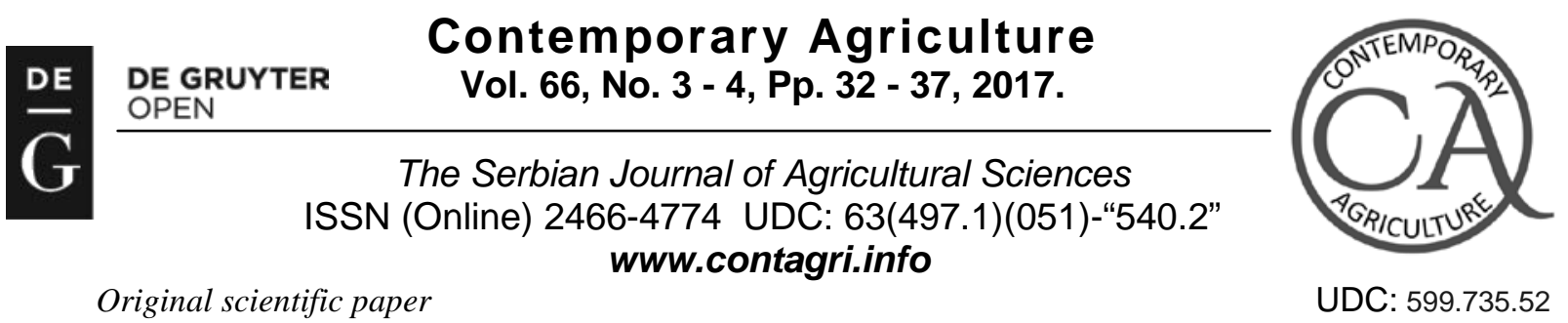

Original scientific paper

DOI:10.1515/contagri-2017-0016

\title{
QUALITY OF MILK FOR CHEESE PRODUCTION ON REGISTERED AGRICULTURAL HOLDINGS IN VOJVODINA
}

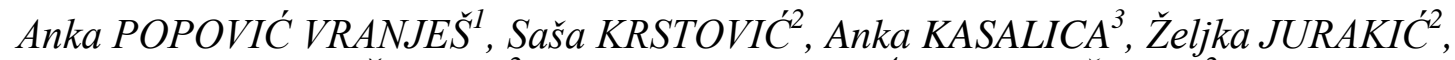 \\ Ljuba ŠTRBAC ${ }^{2}$, Katarina STRUGAR ${ }^{4}$, Momčilo ŠARAN ${ }^{2}$
}

\begin{abstract}
Summary: Currently, milk producers in Vojvodina on registered agricultural holdings (RAHs) have great experience and knowledge in managing their farms, including primary production, processing and sales. However, for a smaller number of manufacturers, there is still room for organizational and technological improvement of production. Nowadays, goat breeding is a very important part of sustainable production, rural development, and represents a very important part of rural development and employment of people. The course of goat breeding in our country is milk-meat, where milk is usually a priority. For the successful production of cheese, the quality of raw milk plays a critical role. It affects the quality of cheese in terms of a chemical composition, microbiological quality, the presence of chemical residues and organoleptic properties. Cheese is mostly made from cow, goat and sheep milk. The valuable components of milk are proteins and fats. These can also be defined as parameters of utilization, since they indicate how much cheese can be obtained from milk. On average, cow milk contains 3.64\% fat, 3.22\% protein, and $8.52 \%$ non-fat dry matter (NFDM). Higher differences in milk fat content (minimum 3.25\%, maximum 4.36\%) were found in milk from RAHs. Recently, the production of milk with higher fat content has become important, since in Serbian milk there is not enough milk fat, so some processors are obliged to import it in the form of butter and cream. In addition to the chemical composition, the microbiological quality of milk is important to maintain successful cheese production. Regarding our findings, the standard plate count (SPC) and the somatic cell count (SCC) in samples from most RAHs did not exceed the values specified in Regulation (EC) 853/2004. Moreover, goat and sheep milk was in agreement with the technological quality of milk for cheese production, in terms of chemical composition.
\end{abstract}

Key words: milk, registered agricultural holdings (RAHs), cheese.

\section{INTRODUCTION}

By creating value-added products, RAHs in Vojvodina increase the profitability of production, since the final product yields a higher price of their own milk compared to the arrangement when milk is sold as raw material to dairy plants. At the same time, European and world trends in consumer demand for traditional production of various types of quality cheeses are followed (Popović-Vranješ, 2015).

Presently, goat keeping is in expansion in Vojvodina (Memiši, 2007). On the other hand, sheep keeping in Vojvodina is mainly done for meat production (primarily lambs), while small number of herds are used for milk production. The sheep milk is primarily processed into cheese or sold to small dairy plants who buy sheep milk. It is particularly significant that more young people decide to deal with this activity, wherein RAH (J.K.) farm from Padina is an example.

In cheese production technology, it is known that the protein content affects the cheese randman. If the protein content is high with some smaller variations, it is expected that the cheese randman is significantly increased.

\footnotetext{
${ }^{1}$ Anka Popović Vranješ, PhD, Full Professor, Institute of Science Application in Agriculture, Bulevar despota Stefana 68b, 11000 Belgrade, Serbia

${ }^{2}$ Saša Krstović, DVM, Research Assistant, Željka Jurakić, mr, Teaching Assistant, Ljuba Štrbac, PhD, Teaching Assistant, Momčilo Šaran, MSc, Teaching Assistant, University of Novi Sad, Faculty of Agriculture, Trg Dositeja Obradovića 8, 21000 Novi Sad, Serbia.

${ }^{3}$ Anka Kasalica, PhD, Principal Research Fellow, JPS Dairy Institute, Autoput za Zagreb 3, Belgrade, Serbia

${ }^{4}$ Katarina Strugar, Provincial Secretariat for Agriculture, Water Management and Forestry, Mihajla Pupina 16, 21000 Novi Sad, Serbia.

•Corresponding author: e-mail: anka.popovic@gmail.com Tel.: +381 214853372.
} 
Consequently, this will affect the profitability of production. The cheese production is similar for milk produced by different animal species, although some modifications need to be made in sheep milk due to the high content of dry matter (Antunec, 1991).

The overall composition of cheese depends mainly on the milk distribution into cheese, as well as on the macro and micro components (total amount of fat, proteins, carbohydrates, ash) and water in milk. Milk also contains other "small" (micro) but nevertheless nutritious components as vitamins, enzymes, hormones and oligoelements. Milk ingredients are highly interconnected. Changing one component can affect the condition of other components. Not only the quantity but also the composition of these components can affect the quality of the produced cheese. Thus, some types of cheese can only be made when all required properties are fulfilled. If the basic composition of the milk deviates from the normal values, the cheese may become too soft or too hard. In the same way, if milk contains less non-fat dry matter (NFDM) $(<8.5 \%)$, the contents of proteins, lactose and mineral substances are lower as well (Salvadori del Prato, 2001). The main reason for low NFDM is low protein content (Foissy, 2004). The quality of final product depends on the overall effects of specific components in raw milk or their combinations, considering other factors related to the production technology, ripening and storage of cheese (Havranek, 2003). Besides the chemical composition, microflora of milk is also very important for effective cheese production, both quantitatively and qualitatively (Forstnerič, 1967). Microorganisms in milk used for the cheese production, both useful and harmful, mainly come from the environment, as well from the formulations for milk curdling. The microflora that comes into the milk from the environment is very heterogeneous due to different hygienic conditions of production. It can be said that all types of microorganisms are harmful if they are above permitted limits. Therefore, taking care of the hygienic quality of milk for cheese, as well as of activities of various microorganisms during cheese production and ripening, gives the opportunity to achieve high quality cheese.

\section{MATERIAL AND METHODS}

Composite milk samples were taken from Lactofreeze on RAHs in Vojvodina and immediately transported to laboratory for analysis. Sheep milk samples were analysed during the first days of lactation.

Analyses of milk were performed in the laboratories of the Department of Animal Science, Faculty of Agriculture, Novi Sad (Republic of Serbia). Standard analysis of the chemical composition was done with the MilkoScan FT + analyzer using the FTIR technique. MilkoScanTM + FT techniques were in accordance with ISO 9622/IDF141:2013 and AOAC official methods 972.16. For the determination of somatic cell count (SCC) in raw milk FossomaticFT FC (ISO 13366-2) was used, and for standard plate count (SPC) BactoScanTM FC + (ISO 16297).

\section{RESULTS AND DISCUSSION}

Milk of ruminants is the finest milk that can be used for cheese production since it contains high amounts of casein which is necessary for the production of good quality curd. Definition of milk that can be applied to any kind of milking animals, reads: "Milk is a product obtained by milking healthy animals, who had proper nutrition and lactation" (Corradini, 1995). In this definition, the factors that can affect milk composition are given simultaneously, while the quantity and the possibilities of milk production in different animals depend on the species. The RAH in Vojvodina predominately breed the Holstein breed, but there are very good farms that breed the Simmental breed.

Table 1 shows the composition of milk on RAHs in Vojvodina. In cheese production, the chemical composition of milk has a special significance regarding both, cheese quality and cheese randman. There are differences in milk composition, SCC and SPC among the individual farms, and therefore the differences in milk quality for cheese production.

Table 1. Milk quality in samples collected from RAH in Vojvodina

\begin{tabular}{|l|c|c|c|c|c|c|c|c|c|}
\hline Manufacturer & $\begin{array}{c}\text { Šajkaš } \\
\text { (T.J.) }\end{array}$ & $\begin{array}{c}\text { Futog } \\
\text { (P.S.) }\end{array}$ & $\begin{array}{c}\text { Kikinda } \\
\text { (S.T.) }\end{array}$ & $\begin{array}{c}\text { Vrbas } \\
\text { (M.I.) }\end{array}$ & $\begin{array}{c}\text { Mužlja } \\
\text { (P. Č.) }\end{array}$ & $\begin{array}{c}\text { Parta } \\
\text { (S.B.) }\end{array}$ & $\begin{array}{c}\text { Mošorin } \\
\text { (P.R.) }\end{array}$ & $\begin{array}{c}\text { Slan- } \\
\text { kamen } \\
\text { (A.C.) }\end{array}$ & $\begin{array}{c}\text { Rusko } \\
\text { selo } \\
\text { (R.M.) }\end{array}$ \\
\hline DM (\%) & 12.26 & 12.01 & 12.77 & 11.35 & 13.35 & 11.92 & 12.2 & 13,00 & 11.3 \\
\hline Fat (\%) & 4.36 & 3.64 & 3.83 & 3.80 & 3.93 & 3.25 & 3.53 & 4.14 & 3.10 \\
\hline Protein (\%) & 3.09 & 3.16 & 3.53 & 3.15 & 3.59 & 2.83 & 3.18 & 3.36 & 3.17 \\
\hline Lactose (\%) & 4.12 & 4.46 & 4.70 & 4.40 & 5.18 & 4.65 & 4.42 & 4.50 & 4.33 \\
\hline NFDM (\%) & 7.9 & 8.37 & 8.94 & 7.55 & 9.55 & 8.67 & 8.67 & 8.86 & 8.20 \\
\hline SCC (1000/ml) & 390 & 287 & 228 & 240 & 220 & 330 & 874 & 320 & 350 \\
\hline SPC (CFU/ml) & 56,000 & $3,740,000$ & 48,500 & 300,000 & 35,000 & 78,000 & 65,000 & 57,000 & 150,000 \\
\hline
\end{tabular}


DM - dry matter, NFDM - non-fat dry matter, SCC - somatic cell count, SPC - standard plate count.

As can be seen, the fat content in milk from RAHs in Vojvodina was ranged from 3.31\% to 4.36\%. Considering this, it could be concluded that milk, obtained from the RAHs in Vojvodina contains $3.64 \%$ fat on average. Furthermore, total protein content in the same milk samples was ranged from 2.83-3.53\%, with an average value of $3.22 \%$. According to literature data, milk from the territory of Vojvodina contains about 3.30\% protein and 3.70\% fat (Vujičić et al., 1974). In cheese production technology, it is known that protein content affects cheese randman. Therefore, if protein content variation is large, it is realistic to expect a significant deviation in the cheese randman, which affects the profitability of production (Scott, 1998).

Lactose as a free component of milk is important for the microbiological fermentation during cheese production. Lactose is used in the process of lactic acid production and it regulates the $\mathrm{pH}$ of milk and cheese. The content of lactose varies considerably during lactation, but decreases when secretion problems occur. It can be seen in table 1 that lactose content was within characteristic values for milk intended for cheese production. These values were ranged from $4.12-5.18 \%$, with an average content of $4.52 \%$. As for NFDM, the average content was $8.52 \%$. However, NFDM was below $8.5 \%$ in 4 samples which was not in accordance with Serbian regulation (Službeni glasnik RS, 2009). Based on the SPC, most RAHs produced an E-Class milk containing up to 100,000 CFU/ml of microorganisms. Two RAHs produced 1st class milk (100,101 to 400,000 CFU/ml) while one RAH produced 2nd class milk.

SCC in cow milk ranges between 50,000 and 250,000 (Kalit, 1999). In cow milk, an upper limit of 400,000/ml is regulated. Above this limit, there is a possibility that the sub-clinical mastitis occurred (mastitis where symptoms of inflammation are not expressed) (Čačić et al., 2003). Comparing obtained SCC and SPC values to the legally permitted limits, it was found that some samples contained higher values than legally permitted. This means that on some RAHs more work should be done regarding hygiene and health care. The hygienic quality of milk depends on the udder health, the stable hygiene, milking hygiene and milk cooling (Popovic-Vranješ et al., 2012).

The milk that originates from healthy and clean udder does not have high number of microorganisms in most cases. Low yield of cheese is expected from mastitic milk due to low casein value. Many other serious problems arise when veterinarians or breeders use drugs for certain diseases without excluding milk of treated cows from cheese production. The tested milk samples did not contain antibiotic residues.

Cow and goat milk have similar characteristics associated with the production of cheese with minor differences. The cheese made from goat milk ripens more than cow cheese because of the lipolysis. As the goat milk contains smaller fat globules, more fat transfers into cheese, and a smoother texture is obtained in relation to the cow milk cheese. Goat milk is curdling faster than cow milk because it contains alpha-s1 casein (Antunac, 2000). The composition of goat milk changes significantly. This depends on the breed and genotype, the order and stage of lactation and the season (Mioč, 1991). The last two parameters can be interrelated because most dairy goats are at the same stage of lactation at a certain time of the year (Bažanić et al., 2002). From the results given in Table 2, the fat content in goat milk was $2.82-4.10 \%$ with an average value of $3.44 \%$. The protein content was ranged from 2.91 to $3.85 \%$ (mean value of $3.32 \%$ ). Lactose content was $4.15 \%$ on average, ranged from 3.72 to $4.70 \%$. As for NFDM, the average content was $8.27 \%$ (ranged 7.82 to 8.67 ).

Table 2. Goat milk quality in samples collected from RAH in Vojvodina

\begin{tabular}{|l|c|c|c|c|c|}
\hline Manufacturer & $\begin{array}{c}\text { S. Moravica } \\
\text { (L.M.) }\end{array}$ & $\begin{array}{c}\text { S. Krstur } \\
\text { (J.B.) }\end{array}$ & $\begin{array}{c}\text { Srbobran } \\
\text { (M.J.) }\end{array}$ & $\begin{array}{c}\text { B. Karađorđevo } \\
\text { (Ć.M.) }\end{array}$ & $\begin{array}{c}\text { Jazak } \\
\text { (M.Lj.) }\end{array}$ \\
\hline SM (\%) & 11.37 & 12.97 & 11.26 & 12.56 & 10.63 \\
\hline Grease (\%) & 3.10 & 3.93 & 3.27 & 4.10 & 2.82 \\
\hline Protein (\%) & 2.91 & 3.87 & 3.01 & 3.85 & 2.96 \\
\hline Lactose (\%) & 4.31 & 4.70 & 4.20 & 3.72 & 3.85 \\
\hline NFDM (\%) & 8.27 & 8.67 & 7.99 & 8.59 & 7.82 \\
\hline SCC (1000/ml) & 256 & 214 & 796 & 389 & 810 \\
\hline SPC (CFU/ml) & 63,000 & 58,000 & 31,000 & 44,000 & 52,000 \\
\hline
\end{tabular}

DM - dry matter, NFDM - non-fat dry matter, SCC - somatic cell count, SPC - standard plate count.

Considering goat milk composition, some differences among samples were observed. However, according to the Serbian regulation (Službeni glasnik RS, 2009), goat milk samples from all RAHs were in agreement with legal limits. Goat and sheep milk was categorized as the 1 st class because the SPC was below 1,500,000 CFU/ml.

In terms of physical and chemical characteristics, sheep milk differed from cow and goat (Table 3). Sheep milk, compared to cow and goat milk, contained less water and more fat and protein. The content of lactose was very 
similar to other types of milk, which consisted entirely of lactose. Lactose affects the density, osmotic pressure and refractive index and is important in dairy processing technology (Antunac and Havranek, 1999).

In table 3, the composition of sheep milk, obtained from RAH Padina (J.K.) is presented. This RAH produces cheese from sheep milk. The data show that on average, sheep milk contains far more fat and protein than cow milk. This demonstrates that the sheep milk can be characterized as particularly rich (or fat) milk, which is an indicator of good quality milk for further processing.

In comparison with cow and goat milk, sheep milk contains more dry matter fat and protein. The fat of sheep milk is organized as particularly small fat globules, which are very difficult to separate.

According to Serbian regulation (Službeni glasnik RS, 2009), sheep milk must contain at least $5 \%$ milk fat, $5 \%$ protein, and $10.5 \%$ NFDM. Sheep milk contains significant amounts of protein and fat (Tratnik, 1998), which is a good attribute for further processing shows.

Table 3. Sheep milk quality on RAH Padina (J.K.)

\begin{tabular}{|c|c|c|c|c|c|}
\hline Sample number & Fat & Protein & Lactose & DM & NFDM \\
\hline 1 & 7.11 & 5.52 & 4.41 & 18.24 & 11.13 \\
\hline 2 & 5.79 & 5.20 & 4.52 & 16.98 & 11,19 \\
\hline 3 & 5.45 & 5.80 & 4.61 & 17.33 & 11.88 \\
\hline 4 & 6.15 & 5.22 & 4.48 & 17.32 & 11.87 \\
\hline 5 & 4.62 & 5.04 & 4.60 & 15.73 & 11.11 \\
\hline 6 & 6.00 & 5.34 & 4.34 & 17.15 & 11.15 \\
\hline 7 & 6.10 & 6.04 & 4.45 & 18.06 & 11.96 \\
\hline Average & 5.88 & 5.45 & 4.48 & 17.25 & 11.47 \\
\hline
\end{tabular}

DM - dry matter, NFDM - non-fat dry matter.

Given that the quality of milk is the basic prerequisite for obtaining good quality cheese, and that products that are produced on RAHs are consumed by an increasing number of consumers who are interested in products where the path from the "from field to fork" is known, as well as the development of new forms of RAH's products consumption (rural tourism, home sales), the education on RAHs, dairy and cheese producers is becoming a necessary requirement.

A positive example in Vojvodina regarding small family farms, is a rounded production cycle (from animal feed production and animal breeding to milk and cheese production) that is economically profitable. In addition, it is necessary to give all the attention to the quality of milk as a basic raw material, then to the production of cheese and finally not to oscillate their quality.

\section{CONCLUSION}

The quality of milk for cheese production from smaller RAHs in Vojvodina has not been sufficiently explored. Based on the above, the following can be concluded:

Milk for cheese production on small farms in Vojvodina is good for cheese production, in terms of its important components - fat (3.64\%), protein (3.22\%), lactose (4.52\%) and NFDM (8.52\%). However, NFDM was below legal limits in samples from 4 RAHs. Somatic cells were within the permitted level $(296,000 / \mathrm{ml})$, except in case of one producer where the number was above the maximum permitted level $(874,000 / \mathrm{ml})$. Based on the SPC, most RAHs produced an E-Class milk. Two RAHs produced 1st class milk and while one RAH produced 2nd class milk.

Goat milk on average contained: $3.44 \%$ fat, 3.32\% protein, $4.16 \%$ lactose and $8.27 \%$ NFDM. According to the SCC and the SPC, goat milk was suitable for cheese production.

Sheep milk showed good quality in terms of composition, and on average it contained $5.88 \%$ fat, $5.45 \%$ protein, 4.48\% lactose and $11.47 \%$ NFDM.

Based on the research done, it seems that there is a need for education of producers in order to apply good agricultural and hygienic (GAP/GHP) as well as good veterinary practices (GVP).

\section{ACKNOWLEDGEMENT}

This research is a part of project supporting by Ministry of Education, Science and Technological Development, Republic of Serbia (Project: "Production of hard cheese with added value of milk produced in organic and selfsustaining systems", number TR31095). 


\section{REFERENCES}

ANTUNAC, N., HAVRANEK, J.L.: Production, composition and properties of sheep's milk. Mljekarstvo, 49(4):241-254, 1999. ANTUNAC, N., SAMARDZIJA, D.: Production, composition and characteristics of goat milk. Mljekarstvo, 50(4):297-304, 2000. BAŽANIĆ, R., TRATNIK, LJ., DRGALIĆ, I.: Goat milk: characteristics and possibilities, Mljekarstvo, 52(3):207-237, 2002.

ČAČIĆ, Z., KALIT, S., ANTUNAC, N., ČAČIĆ, M.: Somatic cells and factors affecting their number in milk, Mljekarstvo, 53(1):23-26, 2003.

CORRADINI, C.: Chimica e tecnologia del latte. Tecniche Nuove, Milan, 1995.

EUROPEAN COMMISSION: Regulation (EC) No 853/2004, laying down specific hygiene rules for the hygiene of foodstuffs. Official Journal of the European Union, L139:55, 2004.

FOISSY, H.: Aktuelle Aspekte bei Trinkmilch. Weiterbildungszentrum Salern, Südtirol, 2004.

FORSTNERIČ, F.: Mikrobiologija tvrdih sireva. Mljekarstvo, 17(9):193-198, 1967.

HAVRANEK, J., RUPIĆ, V.: Mlijeko - od farme do mljekare, Hrvatska mljekarska udruga, Zagreb, 2003.

ISO 13366-2: Milk - enumeration of somatic cells - part 2: guidance on the operation of fluoro-opto-electronic counters. International Organization for Standardization, Geneva, 2006.

ISO 16297: Milk bacterial count protocol for the evaluation of alternative methods. International Organization for Standardization, Geneva, 2013.

ISO 9622/IDF141: Milk and liquid milk products -- Guidelines for the application of mid-infrared spectrometr. International Organization for Standardization, Geneva, 2013.

KALIT, S.: Somatic cells and their influence on the production and ripening of Podravac cheese. Master thesis, Faculty of Agriculture, University of Zagreb, 1999.

MEMIŠI, N.: Razvoj kozarstva u Vojvodini, Praktične osnove, 2007.

MIOČ, B., PAVIĆ, V.: Proizvodnja i sastav kozjeg mlijeka u usporedbi s kravljim i ovčjim. Stočarstvo, 45(3-4):117-123, 1991. POPOVIĆ-VRANJEŠ, A., MARKOVIĆ, M., BAĆOVIĆ, S., KUČ, J.: Hygiene in Milk Production, University of Montenegro, Biotechnical Faculty, Livestock Selection Service, 2012.

POPOVIĆ-VRANJEŠ, A.: Specijalno sirarstvo, Novi Sad, 2015.

SALVADORI DEL PRATO O. (2001): "Trattato di Tecnologia casearia." Edagricole-Edizione Agricole della Calderini, Bologna 735-737, 2001.

SCOTT, R., ROBINSON, R.K., WILBEY, R.A.: Cheesemaking practice. Springer Science \& Business Media, 1998.

Službeni glasnik RS: Pravilnik o kvalitetu sirovog mleka 21/2009, 2009.

TRATNIK, LJ.: Mlijeko-tehnologija, biokemija i mikrobiologija, Hrvatska mljekarska Udruga, Zagreb, 1998.

VUJIČIĆ I.F., BAČIĆ B.: Protein contents of milk in Vojvodina, Mljekarstvo, 24(3):50-53, 1974. 


\title{
KVALITET MLEKA ZA PROIZVODNJU SIRA NA REGISTROVANIM POLJOPRIVREDNIM GAZDINSTVIMA U VOJVODINI
}

\author{
Anka POPOVIĆ VRANJEŠ, Saša KRSTOVIĆ, Anka KASALICA, Željka JURAKIĆ, \\ Ljuba ŠTRBAC, Katarina STRUGAR, Momčilo ŠARAN
}

Izvod: Proizvođači mleka u Vojvodini na registrovanim poljoprivrednim gazdinstvima (RPG), danas imaju veliko iskustvo i znanje u upravljanju vlastitim gazdinstvima i to uključujući primarnu proizvodnju, preradu i prodaju. Međutim kod manjeg broja proizvođača još uvek ima dovoljno prostora i za organizacijsko-tehnološko unapređenje proizvodnje. Kozarstvo je danas, veoma značajan deo održive proizvodnje, ruralnog razvoja i predstavlja veoma značajan deo ruralnog razvoja i zapošljavanja ljudi. Smer proizvodnje koza kod nas je mlekomeso, gde je mleko uglavnom prioritetno. Za uspešnu proizvodnju sira u celini, odlučujuću ulogu ima kvalitet sirovog mleka. Ono utiče na kvalitet sireva na bazi svog hemijskog sastava, mikrobiološkog kvaliteta, prisustva hemijskih rezidua i organoleptičkih osobina. Sir se kod nas pretežno pravi od kravljeg, kozjeg i ovčijeg mleka. Vredne komponente mleka su, pre svega, proteini i masti, koji mogu biti definisani i kao parametri iskorišćenosti s obzirom da se na osnovu njihove količine vidi koliko se sira može dobiti iz mleka. Sadržaj mlečne masti kod kravljeg mleka u proseku je 3,64\%, proteina 3,22\%, suve materije bez masti $8,52 \%$. Utvrđene su veće razlike u sadržaju mlečne masti (min. 3,25\%, max. 4,36\%) u mleku pojedinih gazdinstava. Proizvodnja mleka s više masti je značajna, tim više što u novije vreme, u Srbiji nema dovoljno mlečne masti, neki prerađivači su prinuđeni da je uvoze u obliku maslaca i pavlake. Pored hemijskog sastava za uspeh u sirarstvu je važan mikrobiološki kvalitet mleka. Ukupan broj bakterija i sadržaj somatskih ćelija kod većeg broja proizvođača nije prelazio vrednosti određene Regulativom (EC) 853/2004. Kozje i ovčije mleko je u pogledu sastava u proseku odgovaralo tehnološkom kvalitetu mleka za sir.

Ključne reči: mleko, registrovana poljoprivredna gazdinstva (RPG), sir

\author{
Received / Primljen: 16.10.2017. \\ Accepted / Prihvaćen: 24.12.2017.
}

